\title{
Pragmatic Aspects of Tense in English and Arabic: Based on a Neo-SRE Theory
}

\author{
Gehad M. Amin ${ }^{1}$ \\ ${ }^{1}$ Department of English, Zulfi Colledge of Education, Majmaah University, Saudi Arabia \\ Correspondence: Gehad M. Amin, Majmaah University, Riyadh, Saudi Arabia. E-mail: g.amin@mu.edu.sa
}

Received: March 24, 2020

Accepted: May 3, $2020 \quad$ Online Published: May 9, 2020

doi:10.5539/ijel.v10n4p75

URL: https://doi.org/10.5539/ijel.v10n4p75

\begin{abstract}
The hypothesis upon which this paper is based is that in both Arabic and English the notion of tense underdetermines the notion of time, and some pragmatic enrichment is needed to the get at the correct temporal interpretation. In both languages, beside the normal unmarked tense usages, some marked usages of tense are available wherein the tense constructions do not refer to their equivalent temporal intervals; this is done for the sake of rhetorical purposes as illustrated and exemplified. Even the unmarked cases to tense are proven to require, for sound interpretation, the inclusion of pragmatic givens. Many examples are given in both languages showing the pragmatic nature of the temporal interpretive process of tense in terms of the SRE theory where the interrelationship of the three-time intervals speech, event, and reference times (S/TU, E/TSit, R/TT) is based primarily on rather pragmatic parameters within the process of temporal interpretation. Some new treatment is given concerning the theory of tense interpretation which is related to a pragmatic conception of the speaker's temporal projection or "virtuality" via which tenses' inherent three-time points are pragmatically interrelated and arranged in terms of the potential existence of multiple virtual and non-virtual speakers.
\end{abstract}

Keywords: tense, time, SRE theory, relevance, underdeterminacy, pragmatics, English, Arabic

\section{Introduction}

\subsection{Scope and Aim}

This article aims to probe into the pragmatic implications of tense/time relationship. I adopt an eclectic approach involving the descriptive, critical and analytic wherein I probe into the pragmatic analysis of tense and aspect. The focus in this article is on giving evidence for the underlying pragmatic considerations associated with the functional use of tense, both in English and Arabic. The hypothesis upon which this paper is built is that there is a disparity between tense and time. Many theorists adopt this stance (Avanessian \& Hennig, 2012; Charlton, 2014; Dowty, 1979; Fine, 2005; Gennari, 2003; Huddleston, Pullum, et al., 2002; Jackendoff, 2002; Langacher, 2011; Ludlow, 1999; Celce-Murcia \& Freeman, 1999; Tony, 2005; Yule, 1998). Thus, as Gennari (2003) maintains, "the meaning of the tense morpheme alone does not completely determine the temporal interpretation of a sentence" (p. 35). Time can be expressed in many ways in language, yet our focus here is on the morphological shape the verb undergoes to locate a situation in time. It is hypothesized here that the existence of such a shape is not a prerequisite for having the same time denoted by the verb. This presupposition is built on a pragmatic basis, as will be dwelled on, and applies to both English and Arabic, mutadis mutandis.

The other aim is to figure out the pragmatic aspects of the tense theory that seeks to analyze tense in terms of a neo-Reichenbachan theory of three temporal points (i.e., the SRE theories) and its applicability to Arabic in comparison to English. The neo-Reichenbachan theory of Klein (1994) proposes as well three temporal points: TU (Time of utterance), TT (topic time), and TSit (time of situation) which are equivalent of Reichenbach's S, R, and E respectively.

\subsection{Research Questions}

a) Why tense in its pure formal construction is not, in many cases, helpful in assigning equivalent temporal interpretation of utterances?

b) How does Arabic vary from English in terms of tense and aspect configurations as related to SRE theory? 


\subsection{Stating Hypotheses and Presuppositions}

a) There is a gap between tense and temporal reference, and this gap can only be bridged pragmatically; tense in English and Arabic underdetermines its temporal interpretation which requires pragmatic enrichment.

b) The pragmatic area of temporal interpretation in Arabic is wider than that in English.

c) The correlation between the three temporal points will be misdirected and misinterpreted if considered apart from the pragmatic factors, relevant. Topic (reference) time shifts and linkage to situation time and utterance time is purely pragmatic.

\subsection{Procedure and Methodology}

I will start with investigating the pragmatics of SRE temporal approach in English, and then in Arabic to come up with conclusions comparing temporal interpretation in both.

\subsection{Source of Data}

The examples employed in this article are devised, unless otherwise noted, to substantiate for the hypotheses mentioned earlier.

\subsection{Review of Literature}

The literature on tense is so enormous for a single research paper to survey; many linguists, logicians, and even philosophers have approached tense as encoding the concept of time. Readers can refer back to such linguists as (Arche, 2006; Bache, 1995; Binnick, 1991; Bull, 1960; Comrie, 1985; Harder, 1996; McGilvray, 1991; Nordlander, 1997; among many others). Among the literature that relates to the treatment of tense on pragmatic bases is Smith (2007) "Tense and Temporal Interpretation", wherein she investigates tense pragmatically within the framework of DRT (Discourse Representation Theory). The basic idea is that temporal interpretation is determined by interpretive rules that treat the sentence surface structure and the context in which it appears as inputs for sound interpretation (pp. 419-436). The focus is on discoursal context, whereas in this paper is on the extra-linguistic aspects of context in the first place. Likewise, Gennari's (2003, pp. 35-71) "Tense Meanings and Temporal Interpretation" is another study of tense; she explains the effect of tense meaning and Aktionsart properties on temporal interpretation, yet without touching deeply on the inherent pragmatic dimensions of temporal interpretation. That is why this study is established to tackle those inherent pragmatic aspects of tense meaning.

\section{Theoretical Framework}

My treatment of this perspective is based on what is known as the three-time-parameters approach, particularly that of Reichenbach (1947) wherein he distinguishes three temporal indices: 1) speech time (S), 2) event time (E), and 3) reference time (R). The speech time is the moment at which the speech is uttered, the event time is the moment at which the event occurs, and the reference time is the moment in terms of which an event is described or presented (pp. 37-50). Dahl (1985, p. 30) gives a good clarification of Reichenbach's theory:

- Peter has gone away

where $\mathrm{S}$ is the time when the sentence is uttered, E the time when Peter went away, and $\mathrm{R}$ is "some definite time-point between $\mathrm{S}$ and R provided by the context".

Thus, the three moments are interrelated in one way or another. That is to say, the present simple conveys that the three times are simultaneous. The past simple conveys that $\mathrm{E}$ precedes $\mathrm{S}$ which is simultaneous with $\mathrm{R}$. the present and past perfect that the three times are all different. The Future conveys tense that the $\mathrm{E}$ follows $\mathrm{S}$ which is simultaneous with $\mathrm{R}$, while the in future perfect $\mathrm{R}$ is not simultaneous with $\mathrm{S}$, as $\mathrm{R}$ follows $\mathrm{S}$ and precedes $\mathrm{E}$. Consequently, the simultaneity of $\mathrm{R}$ and $\mathrm{E}$ is compatible with simple aspect, while in perfect aspect, $\mathrm{R}$ precedes $\mathrm{S}$ in past and present tense, and follows it in future perfect.

Moreover, the basic analysis will be handled in terms of a neo-Reichenbachan model proposed by Klein (1994). Contrary to the two parameters approaches to tense, the gist of such three-time parameter approaches is that tense does not express a temporal relation between the time of situation and that of utterance, but rather to some other time chosen by the speaker to be the temporal gauge in terms of which the utterance should be temporally understood; this is Reichenbach's reference time (R), or what Klein calls topic time (TT). Temporal (tense/aspect) interpretation is assigned In terms of the temporal relationships: sequence, precedence, coincidence, and even containment of the three temporal points (speech time, reference time, event time (, , R, E), or as Klein names them time of utterance, topic time, and time of situation (TU, TT, TSit)).

The orientation of this paper is specified in the light of a basic tenet of relevance theory, as proposed by Wilson 
and Sperber $(2012,1995)$, i.e., underdeterminacy thesis which expresses the gap between what is said and what is meant. This is not the problem of tense, per se, but of language in general, as it usually underdetermines meaning under the effect of certain extra-linguistic factors. A theory of tense, and even of language, will be complete if it contains all the variable factors that affect interpretation. I believe this might be neither possible nor beneficial, for we need this space of linguistic maneuvering related to the polysemic nature of language which allows for different local and global interpretations. By local and global I mean within the purview of language, and under the effect of extralinguistic parameters respectively. Sperber and Wilson accord with this idea; they maintain that utterances "need not represent or encode the communicator's informative intention in any great detail" (1995, p. 254). The informative intention is one aspect of the extralinguistic parameters that affect meaning interpretation. Carston (2002) considers underdetermanicy as an essential property of natural languages, as "there are no eternal sentences in language" (p. 83).

\section{Tense as Deixis}

The deictic nature of tense makes it difficult to assign its specific temporal meaning on pure semantic bases. The meaning denoted by tense (as a grammatical feature) is, in many cases, underspecified. That is, the morpho-structural configuration of tense in an utterance might fail in its own right to fully elucidate what is communicated temporally. Therefore, some pragmatic enrichment is needed to create a complete picture of temporal meaning. Comrie (1985, p. 19) provides us with striking examples showing the disparity between the logical form of tense construction and the interpretive form:

- I just wanted to ask you if you could lend me a pound

which in most cases cannot be interpreted as a report of the speaker's desire in the past, despite the past-inflected verbs "wanted," and "could."

Comrie's example shows that the use of the past inflection has a pragmatic purpose which is to show politeness, rather than referring to a temporal interval in the past. But what if the speaker intends to refer to the past! Tense, thus, can be used deictically and non-deictically. The same utterance can have two temporal readings with only one intended by the speaker.

\section{Co-Textual and Contextual Effects on Tense Interpretation}

Sometimes the semantic import of the co-text affects tense interpretation; compare the following utterances:

\section{1) a- I'm getting better/sleepy}

b- I'm getting married

where in the first, the present continuous refers to the time being, i.e., the meaning of "now" is unavoidable in interpreting the deictic force of tense. While in the second, the meaning of "now" is not part of the deictic force. Our encyclopedic knowledge of the nature of such states of affairs puts restrictions on the temporal denotation of tense and thus affects interpretation.

Comparing "When you come, I will be making cookies" and "When you come, I will be happy," we get different temporal readings one reading, the TSit precedes the TT, and both succeeds the TU, wherein making cookies (event) and being happy (state of affairs) occur before (and mostly after). There is a possibility that the TSit be, or not, extended to encompass sometime after the TT. In another reading of the second sentence (i.e., the first "because-of" reading), the TSit coincides with and succeeds the TT, with both succeeding the TU. In a nutshell, the following table might clarify the point: $\mathrm{TSit}=\mathrm{X}, \mathrm{TT}=\mathrm{Y}$, and $\mathrm{TU}=\mathrm{Z}, \mathrm{X}_{\mathrm{y}} / \mathrm{Y}_{\mathrm{x}}=$ both times are simultaneous.

Table 1. Temporal processing and pragmatic enrichment

\begin{tabular}{|c|c|c|c|c|c|}
\hline \multirow[t]{2}{*}{ UTTERANCE } & \multicolumn{3}{|c|}{ TEMPORAL STRUCTURE } & \multicolumn{2}{|c|}{ PRAGMATIC ENRICHMENT } \\
\hline & $T$ Sit $=x$ & $T T=y$ & $T U=z$ & yes & No \\
\hline When you come, I will make cookies. & $\begin{array}{l}Z Y_{x} X \\
Z Y X\end{array}$ & & & $\checkmark$ & \\
\hline When you come, I will be making cookies. & ZXYX & & & & $\checkmark$ \\
\hline When you come, I will have made cookies. & ZX Y & & & & $\checkmark$ \\
\hline When you come, I will be happy. & $\begin{array}{l}Z Y X \\
Z Y_{x} X \\
Z X Y X\end{array}$ & & & $\checkmark$ & \\
\hline When you come, I will have been happy. & $\begin{array}{l}Z X Y \\
Z X_{y} Y \\
Z X Y X\end{array}$ & & & $\checkmark$ & \\
\hline
\end{tabular}


In such types of complex sentences, the TT is tied up with subordinate conjunct, while the TSit with the superordinate one. Here a question arises: what temporal structure will look like in simple sentences. So "John has played the match," and "John's playing the match" might be given different temporal interpretation according to context, as in: 1) "and he is taking a shower now", and 2) "for three hours now." Interpreted in terms of context 1, "John's playing the match" occurred before TU and finished, but to context 2, it occurred before and after TU. Consider also the following examples:

2) John came.

3) My keys were in the kitchen.

Here, both sentences are in same tense/aspect form (i.e., past simple), yet the temporal structure is different; this is based on a purely pragmatic notion associated with what is known as Aktionsart: the nature of what the verb denotes, e.g., an event or a state of affairs. In the case of the first sentence, TSit precedes TU, and TT might coincide with TSit or comes after it. TT includes the interval starting with TSit till just before TU. Two temporal structures are available:

a) $X_{y} Y Z$

b) $X Y Z$

and If we consider the verb "come" of some resemblance to a state of affairs, as its actual effect (i.e., the fact that he came) is extended over a period of time till just before TU, then we will have two extra structures:

c) $X_{y} Y_{x} X Z$

d) $X Y_{x} X Z$

where TSit encompasses TT; TT might (or not) be simultaneous with TSit.

In the case of 3, the temporal structure options are:

a) $X Y_{x} X Z$

b) $X Y X Z$

c) $X Y Z$

the structure ' $\boldsymbol{X} Y \boldsymbol{Z}$ ' means that the speaker's first knowledge that the keys were in the kitchen does not coincide with the state of their being in the kitchen, and the keys are no longer in the kitchen. While in "a" and "b" the keys are still in the kitchen, and in "a" only the time when the speaker knew this coincides with their being there (i.e., TSit = TT). In "a", the speaker himself put the keys in the kitchen or saw somebody doing this; this is not the case in "b" where the speaker saw the keys in the kitchen when he entered, leaving them there. In "a" and "b", the TSit is restricted, that is, we assume that it lasts for a specific span, and thus this state of affairs did not obtain at some specific time before TSit and might change at any time after TT. All these temporal interpretations are pragmatically inferred and context-sensitive, as the structure of the sentence tells nothing about it. The interplay of tense which is deictic and Aktionsart (situation type), results in all these variations in temporal structure. The situation type impinges on TT, even though the tense/aspect forms are alike. Thus, in

4) My keys were made of silver

TSit cannot be spoken of as restricted, before and after TT. TSit encompasses TU to form these possible structures:

$-X Y_{x} X Z X$

- X Y X Z X

Here, although the tense is in the past, the temporal characteristic of which is that TSit precedes TU, we notice that TSit succeeds TU as well. This is not explicitly mentioned by the explicature, but pragmatically inferred from our universal knowledge that silver is not liable to change after TU. This temporal interpretation in which TSit succeeds TU does not obtain in 3 wherein TSit precedes TU, unless there be a contextual/co-textual given ruling out this interpretation, e.g.,

5) My keys were in the kitchen, and they are still.

The conjunct "and they are still" is not possible in 4. It is nonsense to say "My keys were made of silver, and they are still." To decide which interpretation obtains at a time cannot be derived from the tense explicature, i.e., logical and propositional forms combined. This requires the availability of contextual givens relevant to the utterance and then conducting pragmatic enrichment accordingly. Thus in 


\section{6) He runs every morning}

with both preceding TU, the original TT succeeds and might coincide with TSit. Then every morning TT is repeated $\mathrm{TT}_{1-\mathrm{n}}$, where "n" refers theoretically to an infinite number of TTs. However, for one reason or another, the $\mathrm{TT}_{\mathrm{n}}$ which coincides with $\mathrm{TSit}_{\mathrm{n}}$ might be limited to an interval after which it comes to an end. A variance does exist in case of factual events or processes where the original TT cannot be thought of as simultaneous with $\mathrm{TSit}$, and $\mathrm{TT}_{\mathrm{n}}$ is not limited to an interval. Consider 7 below:

7) The sun rises every morning

here there is no limited interval for $\mathrm{TT}_{\mathrm{n}}$ to be tied with $\mathrm{TSit}_{\mathrm{n}}$, (unless interpreted in terms of some religious context wherein the sun is said to perish one day). In such factual utterances, the TT might shift in terms of the temporal point intended by the speaker to tie the TSit to it. It might be when he was first aware that the sun rises every morning, when it came to the knowledge of humankind that this case obtains, or even when he might think of a TT that is simultaneous with the original TSit. This interpretation does not obtain in case of habitual utterances. TT shift is purely pragmatic.

In the same utterance, as shown, the TT might precede, precede and include, succeed, or succeed and include, the TU; an additional example is:

8) When I saw him, he was playing football.

Here, the TSit precedes, includes, (and mostly succeeds) the TT, as the playing might have stopped when he saw him. Likewise, the TSit precedes the TU, but it might have been the case that it is extended to include the TU or even succeed it. All these temporal probabilities are not mentioned in the explicature of the utterance. They are liable to change depending on the pragmatic contextual givens relevant to the utterance. If we compare 9 and 10 below:

9) When I saw him, he was putting on the light.

10) *When I saw him, he was having black skin.

Here, the temporal structure will vary due to the variance in the probable temporal length of putting on the light. It is illogical that the TSit includes or succeeds the TU. Putting on the light, in our shared knowledge of the world, would take just the time of pressing the button (if there is no technical problem). In 10, having a black skin representing the TSit will be invariably interpreted as succeeding TU, ruling out abnormal cases. Nothing in both utterances signals this difference; our temporal interpretations are based on purely extralinguistic pragmatic assumptions. In 6, the possibility of TSit succeeding TU is available but might not obtain, which is not the case with 7 where this possibility is nullified. In 10, the possibility is obtainable at and after TU.

\section{A Theory of Topic Time and Temporal Projection}

Concerning the TT (RT of Reichenbach), I propose that it can be easily designated by conceiving the speaker as projecting himself to the original time of utterance. The projected speaker is a virtual one who exists usually at a virtual TU (name it $\mathrm{TU}_{\mathrm{v}}$ ), that functions as the TT (Reichenbach's RT) of the original utterance. For example, in "John played tennis," the original speaker is at TU, while the projected virtual speaker is at the virtual TU which will be the TT of the original utterance. Thus, at TT the virtual speaker will have virtual TSit and TU. The utterance after projection will be "John plays tennis" wherein TU functions as the TT of "John played tennis" where $\mathrm{TU}_{\mathrm{v}}$ (which is, per se, TT) is simultaneous with TSit.

In "John had played tennis," the speaker will project himself temporally twice: he travels backward in time to be the virtual speaker of "He played tennis" which has a relevant $\mathrm{TU}_{\mathrm{v} 1}$. Once more the temporal projection will take place, and the first virtual speaker $\left(\mathrm{S}_{\mathrm{v}}\right)$ will be the virtual speaker of "John plays tennis" which has a relevant $\mathrm{TU}_{\mathrm{v} 2} . \mathrm{TU}_{\mathrm{v} 2}$ is the TT of $\mathrm{TU}_{\mathrm{v} 1}$ and this is the TT of the original TU. Here we have two virtual TUs: $\mathrm{TU}_{\mathrm{v} 1}$ and $\mathrm{TU}_{\mathrm{v} 2}$ plus the original TU. $\mathrm{TU}_{\mathrm{v} 2}$ is the $\mathrm{TT}$ of $\mathrm{TU}_{\mathrm{v} 1}$ which, in turn, is the TT of TU. The past perfect has two TTs related to one another and to TU. If we paraphrase it, we might have this version: John's playing tennis was at a temporal point that precedes another temporal point, tied to some sort of situation, which precedes the temporal point tied to the utterance of "John had played tennis."

In "John has played tennis," there is a double simultaneous projection where the speaker projects himself doubly and simultaneously to be the virtual speaker of "John played tennis" and "John plays tennis" where the $\mathrm{TU}_{\mathrm{v} 1}$ of the first represents the TSit of the original sentence while the $\mathrm{TU}_{\mathrm{v} 2}$ of the second its TT which coincides with TU.

In future tenses, as in "John will play football," the speaker projects himself forward in time. When the event or situation occurs at the specific temporal point, it will be in the present time for the projected speaker, i.e., "John 
plays tennis," where the Tsit, TT, and TU are contemporaneous. The TU $\mathrm{V}_{\mathrm{v}}$ here will function as the TT of the original utterance "John will play Tennis." As to future perfect, in "John will have played tennis, when you come," the modal "will" is tied to the current TU, and the perfect-marker "have" to the TSit of some other event/situation which is the TT. Thus, the TSit of "when you come," which is, per se, the TT of the other superordinate clause "John will have played" comes after TU of the original sentence. The TSit of the superordinate clause precedes both. The following table clarifies the matter:

Table 2. $\mathrm{TT}_{\text {major }}$ selection

\begin{tabular}{|c|c|c|c|c|}
\hline \multicolumn{3}{|c|}{ John will have played tennis } & \multicolumn{2}{|c|}{ When you come } \\
\hline $\mathrm{TU}=\mathrm{Z}$ & $\mathrm{TSit}_{1}=\mathrm{X}_{1}$ & $\mathrm{TT}_{\text {minor } 1}=\mathrm{Y}_{1}$ & TU & $\mathrm{TSit}_{2}, \mathrm{TT}_{\text {minor } 2}$ \\
\hline $\begin{array}{l}Z X_{1} Y_{1} \\
Z X Y\end{array}$ & & & $\mathrm{Z}\left(\mathrm{X}_{2}, \mathrm{Y}_{2}\right)$ & \\
\hline
\end{tabular}

This table displays the temporal characterization of the future perfect. Here $\mathbf{T T}_{\text {minor1 }}$ coincides with $\mathbf{T T}_{\text {minor2 }}$ which, in turn, coincides with $\mathbf{T S i t}_{2}$. This combination of $\mathrm{TT}_{\text {minorl }}, \mathrm{TSit}_{2}$, and $\mathrm{TT}_{\text {minor } 2}$ represents the $\mathrm{TT}_{\text {major }}$ of the whole sentence. The formula of the whole sentence will be ZXY (TU-TSit-TT). $Z$ which is the TU remains constant, $\mathrm{X}_{1}$ takes the role of TSit, and $\mathrm{Y}_{1}, \mathrm{Y}_{2}$, and $\mathrm{X}_{2}$ represents the $\mathrm{TT}_{\text {major }}$ of the whole sentence. In other cases, $\mathrm{Y}_{1}$ might not coincide with $\mathrm{Y}_{2}$ and $\mathrm{X}_{2}$ as in "John will have played tennis, while you come." In such cases, only $\mathrm{X}_{2}, \mathrm{Y}_{2}$ will constitute the $\mathrm{TT}_{\text {major }}$.

Regarding using present tense for scheduled events/situations, as in "The flight arrives next week," there is an encoded pragmatic conventional temporal implicature, so to speak, emanating from shifting from direct explicit future form to the present form. This shows that the situation which will happen in the future and which is temporally linked to TU is scheduled, predetermined, or expressing the speaker's certainty of occurrence. In such utterances, there must be an adverbial that helps shift our temporal interpretation from that of the present wherein the three temporal points (TSit, TT, TU) are contemporaneous to that of the future where TSit follows TU. The basic variance is that in present-form future, or "reduced future" as some linguists might call it (e.g., McGilvray, 1991, p. 42) (contrary to pure future the TSit and TT follow the TU), TT is simultaneous with TU not TSit, i.e., $(\mathrm{Z}, \mathrm{YX})$. The simultaneity of $\mathrm{TT}$ and $\mathrm{TU}$ in present-form future is the cause of the "as-if-happening-now" picture which shows predetermination and/or certainty. The same concept applies to historical present which projects events in the past to a present temporal interval for the sake of vividness.

\section{Temporal Ambiguity}

TT can be ambiguous between different readings or interpretations; this gives rise to temporal ambiguity or non-specificity; so in

11) John found a girl who wore a red skirt

the utterance here might have more than one temporal interpretation depending on which TT the speaker relates the TSit to. We have two TSits, one denoted by the matrix verb "found" TSit 1 and the other by the relative clause verb "wore," TSit ${ }_{2}$ and each TSit can be taken as the TT of the other. It goes for the speaker to choose which TT he is using. The girl's wearing a red skirt can be temporally placed in three positions. If we take the time of John's finding the girl (TSit $\left.{ }_{1}\right)$ as the TT to which the girl's wearing a red skirt $\left(\mathrm{TSit}_{2}\right)$ is related, then TSit ${ }_{2}$ might precede, succeed, or coincide with TT. Thus, we come up with four temporal interpretations: the girl was wearing a red skirt before John found her, after John found her, at the time when John found her, or even all of them:
a) $\mathrm{TSit}_{2}$ Precedes TT
b) $\mathrm{TSit}_{2}$ follows $\mathrm{TT}$
c) $\mathrm{TSit}_{2}$ equals TT
d) $\mathrm{TSit}_{2}$ encompasses TT

Another problem of temporal interpretation arises from TT ambiguity in the sense that TSit can be linked to more than one available TT. Consider the following sentence:

12) John was allowed to travel after two weeks.

Here, we have two TSits: "John's being allowed" and "John's travelling”. The situation denoted by the infinitive "to travel" is ambiguous between two readings; each is based on which temporal point (i.e., TSit ${ }_{1}$ or TU) is 
chosen to relate to $\mathrm{TT}_{\text {major }}$. So, John was allowed to travel after two weeks (from now/from the time he was allowed to). Each temporal point generates a $\mathrm{TT}_{\text {minor }}$ associated with it. If the $\mathrm{TT}_{1}$ chosen is the one simultaneous with $\mathrm{TSit}_{1}$, then the infinitive construction will be ambiguous between past and future readings depending on the context, and if the $\mathrm{TT}_{2}$ chosen is the one simultaneous with the $\mathrm{TU}$, the infinitive situation will have a future reading. If $\mathrm{TSit}_{1}$ occurs before two weeks from $\mathrm{TU}$, then $\mathrm{TSit}_{2}$ gets a past reading. If $\mathrm{TSit}_{1}$ occurs within two weeks from TU, TSit ${ }_{2}$ gets a future reading. The future reading of $\left(\mathrm{TU}, \mathrm{TT}_{\text {minor }}\right)$ will differ from that of $\left(\mathrm{TSit}_{1}\right.$, $\left.\mathrm{TT}_{\text {minor }}\right)$. After selecting one of the minor $\mathrm{TTs}$, the $\mathrm{TT}_{\text {major }}$ is to be related to it, hence the temporal interpretation is processed. $\mathrm{TT}_{\text {major }}$ follows $\mathrm{TU} / \mathrm{TT}_{\text {minor1 }}$ and $\mathrm{TSit}_{1} / \mathrm{TT}_{\text {minor } 2}$, but coincides with $\mathrm{TSit}_{2} / \mathrm{TT}_{\text {minor } 3}$.

Here, a question arises: why do not we process the temporal interpretation in terms of $\mathrm{TSit}_{1}$ and TU directly, without generating $\mathrm{TT}_{\text {minor }}$ for each? The answer is that it is not in all cases that the $\mathrm{TT}_{\text {major }}$ can be related solely and exclusively to TSit. Consider the following sentence:

13) John had been allowed to travel after two weeks.

Here, contrary to the previous past version, the $\mathrm{TSit}_{1}$ is not simultaneous with $\mathrm{TT}_{\text {minorl }}$. The $\mathrm{TT}_{\text {major }}$ is related to three different temporal points here: $\mathrm{TSit}_{1} / \mathrm{TT}_{\text {minorl }}, \mathrm{TSit}_{2} / \mathrm{TT}_{\text {minor2, }}$ and $\mathrm{TU} / \mathrm{TT}_{\text {minor3 }}$. The ambiguity, here, is aggravated. These interpretations are not encoded in the surface temporal structure available. This depends basically on the intended temporal point the speaker uses to associate with the $\mathrm{TT}_{\text {major }}$, and on the degree of temporal disparity between the minor TTs tied to $\mathrm{TSit}_{1}, \mathrm{TSit}_{2}$, and $\mathrm{TU}$. The $\mathrm{TT}_{\text {minor }}$ is thus a virtual temporal point tied to any TSit and TU. It is the task of the speaker to designate which $\mathrm{TT}_{\text {minor }}$ is to be associated with or picked up as the $\mathrm{TT}_{\text {major }}$. $\mathrm{AT}_{\text {minor }}$ might be elevated to be the $\mathrm{TT}_{\text {major }}$ of the whole utterance in the absence of an adverbial designating it. In the previous sentences, the adverbial "after two weeks," has the function of $\mathrm{TT}_{\text {major }}$. The relationship between minor TTs characterizes aspect, while the relationship between minor and major TTs on one side and the TU on the other characterizes tense.

\section{Pragmatic Aspects of the Applicability of Neo-SRE Theory to Arabic}

Books on Arabic grammar state that the verb has two primary forms: perfect (ma: $\left.\mathrm{d}^{*} \mathrm{i}\right)$ and imperfect (Mud*a:ri3) which denotes either "al-7a:l" (present) or "al-Istiqba:l" (future). Adding the morpheme "sa-" or the periphrastic element "sawfa" to the imperfect shifts the temporal reference to the future. The first represents a finished action, the other unfinished action (e.g., Fischer, 2002, p. 96; Socin, 1885, p. 30; Thatcher, 1922, p. 61). Like Arabic, in old English, the dichotomy is past and present only, with present representing present and future time (Baskervill \& Sewell, 1895, p. 106). In the classification of Ibn al-Sarraj (died in 316 A. H.), "al-'amr" is excluded from the classification of verbs types, and the present in Arabic is ambiguous between present and future (1996, p. 38). Verbs in Arabic are classified as well in terms of in/transitivity. This affects the verb form and the temporal characterization ascribed to them (Zeinab, 2018, pp. 229-244). This point is outside the scope of this article.

\subsection{The Perfect Verb}

The perfect $\left(\operatorname{mad}^{*} \mathrm{i}\right)$ in Arabic (preterit in English) is ambiguous between two readings: one which is equivalent to past simple (Historic past) and the other to present perfect. For example:

14) Ja:'a l-rajul/the man came/has come

can be used to have the temporal interpretation of "The man came" and that of "the man has come, with the R point (TT) sometimes simultaneous with E (TSit) and S (TU) respectively. Fehri (2012) accords with the idea of ambiguity ascribed to perfect tense (p. 6).

If the speaker seeks to exclude the past simple reading, he might use the confirmatory particle "qad" which might be close in meaning to "already." So

15) Qad ja:'a 1-rajul/the man has come

is interpreted with the TT co-occurring with the TU, not TSit (i.e., "The man has come," not "The man came"). Haywood and Nahmad (1965) add that the use of "qad" with perfect verbs can be temporally interpreted as equivalent to the pluperfect in English (e.g., "The man had come" (my example)) (p. 100). If what they say is true, the use of "qad" with perfect verbs can have two readings: one equivalent to present perfect, and the other to past perfect.

Likewise, if the speaker seeks to exclude the present-perfect reading in perfect verbs, he might use "Ka:na," which hooks the TSit with another TSit functioning as TT in the past. Thus, we have the following utterances:

16) a- Ja:'a (ج)

b- Qad ja:'a (قداء) 


$$
\text { c- Ka:na (qad) ja:'a (كانَ) (قد) (كاء) }
$$

Table 3. The variance in tense/aspect reading in Arabic from English

\begin{tabular}{|c|c|c|c|c|c|c|c|c|}
\hline \multicolumn{3}{|c|}{$\begin{array}{l}\text { Ja:'a (جاء) } \\
\text { came/has come }\end{array}$} & \multicolumn{3}{|c|}{$\begin{array}{l}\text { Qad ja:'a (قداء) } \\
\text { has come/had come }\end{array}$} & \multicolumn{3}{|c|}{$\begin{array}{l}\text { Ka:na qad ja:'a (كانَ قد جاء) } \\
\text { had come }\end{array}$} \\
\hline $\begin{array}{l}\text { Preterit (past } \\
\text { simple) }\end{array}$ & $\begin{array}{l}\text { Present } \\
\text { Perfect }\end{array}$ & $\begin{array}{l}\text { Past } \\
\text { Perfect }\end{array}$ & $\begin{array}{l}\text { Preterit (past } \\
\text { simple) }\end{array}$ & $\begin{array}{l}\text { Present } \\
\text { Perfect }\end{array}$ & $\begin{array}{l}\text { Past } \\
\text { Perfect }\end{array}$ & $\begin{array}{l}\text { Preterit (past } \\
\text { simple) }\end{array}$ & $\begin{array}{l}\text { Present } \\
\text { Perfect }\end{array}$ & $\begin{array}{l}\text { Past } \\
\text { Perfect }\end{array}$ \\
\hline$\checkmark$ & $\checkmark$ & $x$ & $x$ & $\checkmark$ & $\checkmark$ & $x$ & $x$ & $\checkmark$ \\
\hline \multicolumn{3}{|c|}{ TSit, TT-TU or TSit-TT, TU } & \multicolumn{3}{|c|}{ TSit-TT, TU or TSit-TT-TU } & TSit-TT-TU & & \\
\hline
\end{tabular}

The previous argument clarifies that, in some cases (16a), the "aspect" is not marked at all neither morphologically nor periphrastically. In other cases $(16 \mathrm{~b}, \mathrm{c})$, aspect is periphrastically marked by using some other particles or linguistic elements (e.g., "qad" and/or "Ka:na"). The use of "qad" with perfect verbs is ambiguous, as well, between two aspectual readings according to context.

Unlike English wherein the present is used to state facts, the perfect (al-ma:d*i) in Arabic can be used to serve this function. For example:

17)

(la-qad kafara l-lazi:na qa:lu 'inna l-la:ha huwa l-masi:7u bnu Maryam)

\{They disbelieve(d) those who said that Allah is Jesus, son of Mary\} (5/72, p. 74).

Here the perfect verb "kafara" is used to state a fact not merely to refer to an event that happened in the past. In most translations of Qur'an, the verb "kafara" is not translated to English in the past, as its form in Arabic denotes, but in the present factual form.

Fischer (2002) claims that the use of factual perfect verbs in Arabic is exclusive to the pre-classical era (p. 102). However, the previous Qur'anic verse refutes this. Here despite the past form of the verb "kafara," the TT is simultaneous with the TU. In such usage, the perfect (parallel to English preterit, past) in Arabic is equivalent to the imperfect (factual present) in English. To add the progressive aspect in Arabic, the imperfect can be used. Compare:

18) a- علمت أنك ذكي

(3alim-tu 'anna-ka zakiy-yun, I knew/know that you are smart)

$$
\text { b- كنت أعلم أنك ذكي }
$$

(kont-u 'a3lam-u 'anna-ka zakiy-yun, I *was knowing (used to know) that you are smart)

$$
\text { c- أعلم أنك ذكي cann }
$$

('a3lam-u 'anna-ka zakiy-yun, I know/*am knowing that you are smart)

This case might be clearer with dynamic verbs to which, unlike stative verbs, the progressive form is applicable.

19) a- جريت كل يوم

(jara-ytu kol-la yawm, I ran/run everyday)

$$
\text { b- كنت أجري كل يوم }
$$

(Kont-u 'ajri kol-la yawm, I was running everyday)

$$
\text { أجري كل يوم c- (20) }
$$

('ajri kol-la yawm, I run/am running everyday)

The first and last are in perfect and imperfect forms of the verb. Both can be used as equivalent to "factual present" in English, yet the last has a sense of continuity and "ongoingness" in the present time. The middle formula is a mixture of the periphrastic past "kontu" and the imperfect "'a3lamu," which, combined, adds an aspectual sense of "ongoingness" in the past.

This type of factual preterit is widespread in Qur'an, e.g.:

20) $\{$ وكان الله غفور ا رحيمان

(wa-ka:n-a l-la:h-u 8afu:r-an ra7i:m-a, For Allah is Oft-forgiving, Most Merciful) (4/96, p. 60) 
here, if translated literally in terms of the locutionary form, "Ka:n-a" equals "was." Yet the function here varies from the form, as in context, the perfect verb in Arabic can be used in equivalence to factual/habitual present in English. Here the TT is all-encompassing; it contains TSit and TU. However, the temporal interpretation will differ, if we ascribe this utterance to a human being, e.g., "Ka:n-a Ahmed 8afu:r-an ra7i:m-a, Ahmed is/was merciful, compassionate," where the preterit interpretation is applicable, contrary to the previous example. In the first example, the preterit is ruled out, due to contextual restrictions associated with our/some people's knowledge of what is/is not ascribable to God.

After "إذإl" "iza/if (or when), the past-form verbs in Arabic can refer to the future, e.g,.

إذا جاء أخوك، اذهب لبيت عمك (21)

('iza: ja:'a 'a5u:k, ‘izhab l-bayt 3ammik,' if/when your brother comes, go to your uncle's house).

\subsubsection{Arabic Speech Act Verb Form}

Other uses of the Arabic perfect (Ma:d*i) form is equivalent to performative speech acts as proposed by Austin (1962). For example:

22) a- هل ستمنحني بعض المال؟

(Hal sa-tmna7-u-ni ba3d*-a l-ma:1? Shall you impart some money on me?)

$$
\text { b- منحت ذنا }
$$

(Mana7-tu-ka za:lik, I impart(ed) it on you).

Although the verb "mana7-tu-ka" (gave/imparted) is perfect in form, it has the performative function of ('amna7uka, give/impart), i.e., "I hereby give you the money." Thus, in Arabic, the past-form verb is used to refer temporally to the present if used performatively (i.e., 'insha:', انشاء). It also refers to the future in case of invocation:

رحمه الله

\section{(ra7ima-hu 1-la:h, May Allah forgive him)}

where the past-form is used to denote futurity, and "presentness" as well. This means that the present-form verb used in English to establish performatives has a past-form verb equivalent in Arabic. If we compare Austin's prototypical example "I name this ship Queen Elizabeth" with this part of a Qur'anic verse:

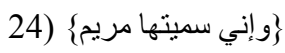

(wa-'inni sammay-tu-ha Maryam; [And] I (have) named her Mary) (3/36, p. 39).

I claim that the past-tense verb "samma" in "sammay-tu-ha" is used performatively, not indicatively, to mean (I name her Mary) where the past-form verb refers temporally to the present.

This argument is closely connected to Austin's dichotomy of "constatives" and "performatives. There is a specific type of present simple which is not regressive or anaphoric; it is related to Austin's (1962) speech act analysis wherein he speaks about "saying is doing." I observe that this type of simple present (used in speech acts) is close to the progressive version:

25) I, hereby, declare the beginning of the festival

where the temporal start point is the TU, as in the progressive version "The festival is beginning". Here, there is no temporal disparity between the declaring and the beginning of the festival. But this disparity might arise if there is a contextual clue for it:

26) I declare the beginning of the festival on Thursday, 12 July.

Here, there is a contextual clue that the declaration is before what is being declared. The present, thus, can be used to temporally refer to Past (historic present), Past + present (+ future) (habitual present), Past + present + future (factual present), Present (speech-act present), and Future (calendaric present) where for each one of these uses there is a pragmatic effect and rhetorical purpose, as aforementioned.

The past, in its turn, is used in some contexts to refer not to past events only; the reference may be extended to include the present and future time. In

27) You want to break up with me, after I loved you

the verb "loved" is morphologically inflected to refer to the past, yet the state of love may still be applicable in the present and future time. The semantic nature of stative verbs renders their past-tense form multi-temporal. 
The following example is also expressive:

28) Waiter: Did you want something, Sir.

Here although the question is temporally past in form, yet present in function. The temporal reference pertains to the present time and perhaps the near future.

\subsubsection{Other Unmarked Cases}

One of the strange cases of perfect verbs is that they can be used to denote the future in conditional constructions. Thus, in a sentence like

29) (29)

('in nas*art-a-hu nasara-k, if you *supported (i.e., support/*will support) him, he will support you)

the locutionary form of the verb is that of the past "nas*ara" (supported), nonetheless, it can be temporally interpreted in the future. Some other utterances with different perfect/imperfect verb forms can have the same function, e.g.:

30)

('in nas*art-a-hu yans*ork, if you *supported (i.e., support/*will support) him, he supports/ will support you).

إن تنصره ينصرك (31)

('in tans*or-hu yans*or-k, if you support (*will support) him, he supports/will support you).

32)

('in tans*or-hu nas*ara-k, if you support (*will support) him, he *supported (i.e., support/will support) you).

Another example is given by Forbes $(1863$, p. 83):

33) ما تصنع صنعت

(ma tas*na3 s*ana3t-u, what you do, I (*did) will do).

The first verb "tas*na3" (do) is in the present form, the second "s*ana3t" (did) in the past, nonetheless both are used to be temporally interpreted in the future. In such cases, the SRE configurations cannot be conducted in terms of the locutionary form of verbs, otherwise, we will get counter-factual interpretations.

\subsection{The Imperfect}

As mentioned earlier, the imperfect is used to denote unfinished actions in the present moment. Together with the prefix sa- or the periphrastic auxiliary "sawfa", the imperfect refers to the future. In context, the imperfect can also refer to the future in its own right without attaching anything to it. So in a context where one gives directions or description of some future procedures or actions, the imperfect can be used in isolation from "sa-" and "sawfa":

34) يذهب يوسف إلى أبينا ويستأننه ثم يعود

(yazhab-u Yusuf-u 'ila 'ab-i:na wa yast'azin-u-hu thumma ya3u:d-u, Joseph goes to our father, take his permission, and then comes back).

This usage is equivalent to English, where the present-form verbs can be used to denote the future. The imperfect is also used to show the aspectual continuity of a situation at the moment or at several intervals (i.e., habitual present):

(35) ها هو يخرج من الغرفة (الآن)

(ha-howa ya5ruj-u min-a 1-8orfat-i (1-'a:n-na), he is getting out of the room (now))

بذهب أحمد إلى المسجد كل يوم (Y)

(Yazhab-u Ahmed 'ila 1-masjid-i kol-la yawm-in, Ahmed goes to the mosque every day).

Continuity and habitualness in the past are denoted by the addition of the perfect "ka:na" to the imperfect verb.

كان يعلب الكرة (Ka)

(Ka:na yal3ab-u 1-korat-a, he was playing football)

كان يلعب الكرة كل يوم (K8)

(Ka:na yal3ab-u 1-korat-a koll-a yawm, he was playing football every day).

These examples show, respectively, the effect of co-text on temporal interpretation in terms of continuity and 
habitualness. The temporal reference of the verb "yal3ab-u" (play) is affected by the addition of "koll-a yawm" which shifts it from showing continuity over some specific time to showing habitualness (continuity at interrupted intervals). The SRE configuration will differ in both cases. This configuration is conceptualized in terms of our perception of how things go in the external reality (the world as we perceive it). The TSit is stretched to include some usually uninterrupted temporal interval. In the second, this cannot be the case; the TSit cannot be thought of as continuous with the addition of "koll-a yawm," as our perception of the world denies the possibility of having someone playing football every day without interruption.

As Haywood and Nahmad (1965) illustrate, the future perfect in Arabic is expressed by "using the imperfect of "كان" with the perfect of the verb concerned" (p. 114). They provide the following example:

يكون زيد (قد) كتب (39)

(yaku:n-u z*ayd-un (qad) katab-a/ Zayd would have written).

After لكي- (7atta, likai; for, to) the present-form verb can be used to refer to the past as in:

40) سار حتى يدخل المدينة (كa)

(Sa:r-a 7atta yad5ul-a 1-madinah; he walked to enter the city).

His entering the city might be in the past or future according to context and whether the $\mathrm{TSit}_{2}$ precedes or succeeds the TU. Here, the meaning of "7atta" will change if we use the past-form verb i.e., "sa:ra 7atta da5ala 1-madinah; he walked till he entered the city). Likewise, after لم ولما (lam-lamma, never+verb) the present-form verb refers to the past, including the present moment (speech time):

لم يأت البارحة (41)

(lam ya't-i l-bari7a-ta; he did not come yesterday)

42)

(lamma yad5ul-i l-'i:ma:n-u fi qulu:bi-kum; For not yet has Faith entered your hearts) (49/14, p. 366).

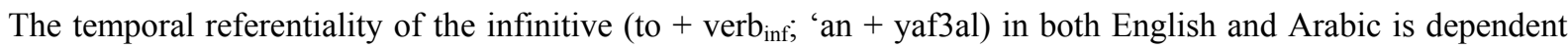
on the co-text in which the construction occurs. Thus, in the following examples the same construction will have different temporal readings:

$$
\begin{aligned}
& \text { 43) a- أخبرته أن يذهب لأمه البارحة } \\
& \text { b- أخبرته أن يذهب لأمه غدال }
\end{aligned}
$$

('a5bart-u-hu 'an yazhab-a 1-'omi-hi 1-bari7a-ta/8ad-an; I asked him to go to/visit his mother yesterday/tomorrow).

The infinitive construction ('an yazhab-a; to go to/visit) is temporally neutral and under the effect of co-text, it can be used to refer to the past, the present or even the future. As previously noted, this phenomenon exists in English; the verb-tense form might not be denotative of the normally equivalent time, as in "I will/would live here" where the past-form "would" does not refer to the past, but it denotes, Yule (1998) states "remoteness of possibility" (p. 59); Bybee (2010) speaks of "degrees of remoteness" in tense system (p. 151). The same thing applies to

44) It may/might rain later.

45) I can/could offer you some advice.

Moreover, the past-verb forms used in sentences showing hypothetical counterfactual situations (irrealis) do not refer nonetheless to the past:

46) If I were you, I would accept the scholarship.

47) I wish I had my Jacket.

In such examples, though they are temporally past in form, the irrealis "were" and "had" do not refer to the past but to some present point. Stalnaker (2014) maintains such argument, as he provides a pragmatic framework for modal analysis (pp. 126-160). Moreover, in reported speech, the present-form verb can be used to refer to the past (e.g., "He said "I am not coming to the party"); the use of past tense (e.g., used to) sometimes bears an implication of something happening in the present. So, in "he used to eat chocolate" implicates "he does not eat chocolate at the present time." This is another dimension of implicative temporal analysis which Levinson (2000, p. 95) following Harnish (1991, p. 354) surveys to show the temporal implicature. 


\subsection{Marked Use of Tense}

In Arabic, it is widely noticed that some verb-tense forms are used markedly for some rhetorical purposes to refer temporally to non-equivalent time. As aforementioned, this is available in English via using, for example, historic present in narratives for past events. I found many marked usages of verb-forms in Arabic, especially in Qur'anic text where past-form verbs are used to refer temporally to the future, as in:

48)

(wa-min 7aythu 5aragt-a fa-walli wajhak-a shatr-a 1-masjid-iI 1-7ara:m)

The historic present is used as well in Qur'an as in:

49) \{ومن الناس من يقول ءامنا بالله وباليوم الآخر

(wa-min-a n-na:s-I man yaqu:1-u 'a:man-na: bl-la:h-I wa-1-yawm-I 1-'a:5ir/Of the people there are some who say: "We believe in Allah and the Last Day;" but they do not (really) believe $(2 / 8$, p. 8$)$

here the event happened in the past but the Qur'an uses the historic present to provide a vivid image and enrich the hearer/reader's sensation of the whole situation. Miscellaneous examples do exist wherein such past-form verbs are ambiguous between multiple temporal readings, as in:

50)

(wa-'iza qi:l-a la-hum la tufsidu: fi-l-'ard-i qa:lu: 'innama: na7n-u musli7u:n/ When it is said to them: "Make not mischief on the earth," they say: "Why, we only Want to make peace! $(2 / 11$, p. 8$)$

here the past-form verb "qa:lu:" (they said) is ambiguous between the past and present reading; that is why it is translated (they say) in most translations of Qur'an not only the one I adopted in this paper. A series of past-form verbs are used in this chapter of the Qur'an wherein the past-inflected verbs are used to denote the relative present/future or at least used ambiguously so that they can have more than one temporal denotation. The use of past-inflected verbs to denote the future is ubiquitous in Qur'an; here is another striking example:

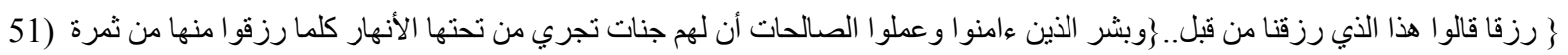

(wa-bashshir-I 1-lazi:na 'a:manu wa-3amilu s*-s*a:li7at-I 'anna lahum janna:t-un tajri min ta7t-i-ha 1-'anha:r kulama: ruz*iqu min-ha min thamarat-in riz*q-an qa:lu haza 1-lazi ruz*iq-na min qabl/ But give glad tidings to those who believe and work righteousness, that their portion is Gardens, beneath which rivers flow. Every time they are fed with fruits therefrom, they say: "Why, this is what we were fed with before ..." $(2 / 25$, p. 9$)$.

In this verse, a depiction is given of the pleasures that will be imparted upon the believers in paradise, a situation which is yet to come, however, the passive past form of the verb "ruz*iqu" is used to emphasize the whole picture as though the listener/reader is retrieving a memorable situation that has already happened.

52)

(wa-qulna (i)hbit*u min-ha jami:3-an fa-'imma ya'tyann-akum mini huda-n fa- man tabi3a huda:I fa-la 5awf-un 3alyhim wa-la hum ya7z*anu:n/We said: "Get ye down all from here; and if, as is sure, there comes to you Guidance from me, whosoever follows My guidance, on them shall be no fear, nor shall they grieve.) (2/38, p. 10).

The past form verb "tabi3a" is used in a context of imperative and present form verbs that denote futurity, i.e., "“ihbit*u," and "ya'ti-yannakum." If consistency is maintained, it should be said "yattabi3" in the present form. But the use of the past form is a marked case where one feels a sudden temporal shift segregating the picture being displayed into two intervals.

53) \{ أتى أمر الله فلا تستعجلوه

('ata: 'amr-u 1-la:h-I f-la tasta3gilu:h; (Inevitable) cometh (to pass) the Command of Allah, seek ye not then to hasten it) $(16 / 1$, p. 171).

Here the past-form verb 'ata' is used to describe an event that is deemed to happen; this might have the rhetorical pragmatic purpose of emphasizing the inevitability of the situation being described or talked about. The meaning is, the command of Allah will certainly come to pass, as though it has already passed. Qur'anic text is full such marked tense manipulation employed to enrich the rhetorical pragmatic taste of the text.

\section{Conclusion}

In a nutshell, the following conclusions are reached:

1) Encoding time in language, as shown in English and Arabic is conducted via pairing it with the relevant 
pragmatic aspects associated with it.

2) TT is some sort of projection time. The $\mathrm{TT}_{\text {minor }}$ is a virtual temporal point tied to any TSit and TU. It is the task of the speaker to designate which $\mathrm{TT}_{\text {minor }}$ is to be associated with or picked up as the $\mathrm{TT}_{\text {major }} . \mathrm{A} \mathrm{TT}_{\text {minor }}$ might be elevated to be the $\mathrm{TT}_{\text {major }}$ of the whole utterance in the absence of an adverbial designating it. The relationship between minor TTs characterizes aspect, while the relationship between minor and major TTs on one side and the TU on the other characterizes tense.

3) The pragmatic nature of TT designation; introducing the new notion of TT shift and multiplicity, and providing a new treatment paving the way for a pragmatic theory of topic time.

4) Examples are given in English and Arabic clarifying the marked and unmarked uses of tense for the sake of pragmatic purposes, and substantiating the underdeterminacy thesis and the hypotheses presupposed in this paper; the historic present in English and the Arabic use of the past-verb form to refer to the future as in 48, for example, are cases in point. Likewise, in English, the past form of some modals e.g., can, will, may, can be used for future reference as in 28 .

5) In English the present-verb form is used for performative speech act uses, while in Arabic the past is used for this purpose; see examples 22, 23, 24, and 25. The past-verb form perfect in Arabic (i.e., preterit in English) is used in many cases to have the function of factual/habitual present in English; see examples 17, 18, 19, and 20.

6) The present in Arabic and English is multi-functionally used for present and future, and even markedly for the past via historic present.

7) The past-verb form in Arabic can be used to have a temporal reading parallel to that of the present perfect in English; see example 16. Examples 27 and 28 show that the past-form verb might not be temporally interpreted as referring or at least exclusive to the past.

8) In Arabic, the "aspect" might not be marked at all neither morphologically nor periphrastically as in $35 \mathrm{a}$; In other cases $(16 \mathrm{~b}, \mathrm{c})$, aspect is periphrastically marked via using some other particles and linguistic elements (e.g., "qad" and/or "Ka:na"). The use of "qad" with perfect verbs is ambiguous, as well, between two aspectual readings according to context.

\section{Acknowledgments}

The author would like to thank Deanship of Scientific Research at Majmaah University for supporting this research under project no. R-1441-120

\section{References}

Arche, M. (2006). Individuals in Time: Tense, Aspect and the Individual/Stage Distinction. Amsterdam: John Benjamins. https://doi.org/10.1075/la.94

Austin, J. L. (1962). How to do things with words. Cambridge: Harvard University Press.

Avanessian, A., \& Hennig, A. (2012). Present Tense: A Poetics (Schott, N. \& Daniel, H., Trans.). London: Bloomsbury.

Bache, C. (1995). The Study of Aspect, Tense and Action: Towards a Theory of the Semantics of Grammatical Categories. Frankfurt am Main: Lang.

Baskervill, W. M., \& Sewell, J. W. (1985). An English Grammar. New York: American Book Company.

Beheydt, G. (2005). The Absolute and Relative Present Tense with Future Time Reference in English and Dutch. In B. Hollebrandse, v. H. Angeliek \& V. Co (Eds.), Crosslinguistic Views on Tense, Aspect and Modality. Amsterdam: Rodopi.

Bull, W. (1960). Time, Tense and the Verb. Berkeley: University of California Press.

Bybee, T. (2010). Language, Usage and Cognition. Cambridge: Cambridge University Press. https://doi.org/10.1017/CBO9780511750526

Carston, R. (2002). Thoughts and Utterances: The Pragmatics of Explicit Communication. Blackwell, Malden. https://doi.org/10.1002/9780470754603

Celce-Murcia, M., \& Diane, F. (1999). The Grammar Book. Washington: Heinle \& Heinle.

Charlton, W. (2014). Metaphysics and Grammar. Bloomsbury: London.

Chovanec, J. (2014). Pragmatics of Tense and Time in News. Amsterdam: John Benjamins. https://doi.org/10.1075/pbns.253 
Comrie, B. (1976). Aspect: An Introduction to the Study of Verbal Aspects and Related Problems. Cambridge: Cambridge University Press.

Comrie, B. (1985). Tense. Cambridge: Cambridge University Press. https://doi.org/10.1017/CBO9781139165815

Dahl, O. (1985). Tense and Aspect Systems. Oxford: Blackwell.

Dowty, D. (1979). Word Meaning and Montague Grammar. Dordrecht: Reidel. https://doi.org/10.1007/978-94-009-9473-7

Fehri, A. (2012). Key Features and Parameters in Arabic Grammar. Amsterdam: John Benjamins. https://doi.org/10.1075/la.182

Fine, K. (2005). Modality and Tense: Philosophical Papers. Clarendon: Oxford. https://doi.org/10.1093/0199278709.001.0001

Fischer, W. (2002). A Grammar of Classical Arabic. New Haven: Yale University Press.

Forbes, D. (1863). Grammar of the Arabic Language. London: W. H. Allen \& Co.

Frege, G. (1984). Collected Papers. Oxford: Oxford University Press.

Gennari, S. (2003). Tense Meanings and Temporal Interpretation. Journal of Semantics, 20, 35-71. https://doi.org/10.1093/jos/20.1.35

Greenbaum, S. (1996). The Oxford English Grammar. Oxford: Oxford University Press.

Grice, P. (1989). Studies in the Ways of Words. Cambridge: Harvard University Press.

Harder, P. (1996). Functional Semantics: A Theory of Meaning, Structure and Tense in English. Berlin: Mouton de Gryuter. https://doi.org/10.1515/9783110818758

Harnish, R. (1991). Logical Form and Implicature. In S. Davies (Ed.), Pragmatics (pp. 346-364). Oxford: Oxford University Press.

Haywood, J., \& Nahmad, H. M. (1965). A New Arabic Grammar of the Written Language. London: Lund Humphries.

Huddleston, R., Pullum, G., et al. (2002). The Cambridge Grammar of the English Language. Cambridge: Cambridge University Press. https://doi.org/10.1017/9781316423530

Ibn al-Sarraj, M. (1996). al-'Usu:l fi-n Na7w (Vol. 1). Beirut: Al-Resalah.

Jackendoff, R. (2002). Foundations of Language: Brain, Meaning and Grammar Evolution. Oxford: Oxford University Press. https://doi.org/10.1093/acprof:oso/9780198270126.001.0001

Langacker, R. (2011). The English Present: Temporal Coincidence vs. Epistemic Immediacy. In A. Patard \& F. Brisard (Eds.), Tense, Aspect and Epistemic Modality. Amsterdam: John Benjamins. https://doi.org/10.1075/hcp.29.06lan

Leith, M., \& Cunningham, J. (2000). Modeling Linguistic Events. In H. Barringer et al. (Eds.), Advances in Temporal Logic (pp. 207-222). Dordrecht: Springer. https://doi.org/10.1007/978-94-015-9586-5_11

Levinson, S. (2000). Presumptive Meanings: The Theory of Generalized Conversational Implicature. Massachusetts: MIT. https://doi.org/10.7551/mitpress/5526.001.0001

Ludlow, P. (1999). Semantics, Tense, and Time: An Essay in the Metaphysics of Natural Languages. Massachusetts: MIT Press. https://doi.org/10.7551/mitpress/6170.001.0001

Lyons, J. (1969). Introduction to Theoretical Linguistics. London: Cambridge University Press.

Lyons, J. (1977). Semantics (Vol. 2). Cambridge: Cambridge University Press.

McGilvray, J. (1991). Tense, Reference \& Worldmaking. London: McGill-Queen's University Press.

Michaelis, L. (2006). Time and Tense. In B. Aarts \& A. McMahon (Eds.), The Handbook of English Linguistics. Oxford: Blackwell.

Nordlander, J. (1997). Towards a Semantics of Linguistic Time. Uppsala: Swedish Science Press.

Prior, A. (1968). Papers on Time and Tense. Oxford, Clarendon.

Reichenbach, H. (1947). Elements of Sympolic Logic. London: McMillan.

Smith, C. (2007). Tense and Temporal Interpretation. In K. Zagona (Ed.), Lingua (Vol. 117, pp. 419-436). https://doi.org/10.1016/j.lingua.2004.10.005 
Smith, C. (2008). Time with and without tense. In J. Guéron \& J. Lecarme (Eds.), Time and Modality. Dordrecht: Springer. https://doi.org/10.1007/978-1-4020-8354-9_10

Socin, A. (1885). Arabic Grammar: Paradigms, Literature, Chrestomathy, and Glossary. London: Carlsruhe and Leipsic Reuther.

Sperber, D., \& Wilson, D. (1995). Relevance, Communication and Cognition (2nd ed.). Cambridge: Blackwell.

Stalnaker, R. (2014). Context. Oxford: Oxford University Press. https://doi.org/10.1093/acprof:oso/9780199645169.001.0001

Thatcher, W. (1922). Arabic Grammar of the Written Language (2nd ed.). London: Heidelberg.

Tony, P. (2005). A Concise Grammar for English Language Teachers. Applewood Heights, Dublin: TP Publications.

Wilson, D., \& Sperber, D. (2012). Meaning and Relevance. Cambridge: Cambridge University Press. https://doi.org/10.1017/CBO9781139028370

Young, D. J. (1984). Introducing English Grammar. London: Hutchinson.

Yule, G. (1998). Explaining English Grammar. Oxford: Oxford University Press.

Zeinab, T. (2018). The classification of the Verb in the Arab Grammatical Tradition. In G. Ayoub \& K. Versteegh (Eds.), The Foundation of Arabic Linguistics (Vol. 94, pp. 229-244). Leiden: Brill.

\section{Copyrights}

Copyright for this article is retained by the author, with first publication rights granted to the journal.

This is an open-access article distributed under the terms and conditions of the Creative Commons Attribution license (http://creativecommons.org/licenses/by/4.0/). 